\title{
PERENCANAAN PENGELOLAAN SAMPAH DI JALUR PENDAKIAN TAMAN NASIONAL GUNUNG RINJANI
}

\author{
Waste Management Plan at Hiking Track of Mount Rinjani National Park \\ Maiser Syaputra \\ Jurusan Kehutanan, Fakultas Pertanian, Universitas Mataram \\ Jalan Pendidikan No. 37 Mataram \\ Email : syaputra.maiser@gmail.com
}

\begin{abstract}
There are four hiking track in the Gunung Rinjani National Park area, namely Senaru, Sembalun, Timbanuh and Aik Berik. In 2016 there were 93,018 visitors at Mount Rinjani National Park. The large number of visitor can be a potential because it contributes to state revenues, but on the other side the presence of waste become manager's homework because the higher number of visitor occurs waste also getting bigger. At present Mount Rinjani National Park does not have a waste management plan, so this study aims is to develop a waste management plan in the hiking track of Mount Rinjani National Park. This study uses several methods, like literature studies, interviews and discussions and field surveys. Based on the results of the study, waste management planning on the hiking track of Mount Rinjani National Park can be formulated into five aspects : operational, institutional, regulatory, financing, and community roles.
\end{abstract}

Keywords: Waste, planning, TNGR

\section{ABSTRAK}

Terdapat empat jalur pendakian wisata di kawasan Taman Nasional Gunung Rinjani yaitu Senaru, Sembalun, Timbanuh dan Aik Berik. Pada tahun 2016 jumlah pengunjung Taman Nasional Gunung Rinjani berjumlah 93.018 orang. Besarnya kunjungan wisatawan ini dapat menjadi potensi karena berkontribusi dalam pendapatan negara namun disisi lain keberadaan sampah menjadi pekerjaan rumah pengelola karena semakin tinggi angka kunjungan wisatawan maka kecenderungan yang terjadi adalah timbunan sampah yang dihasilkan juga semakin besar. Saat ini Taman Nasional Gunung Rinjani belum memiliki rencana pengelolaan sampah, untuk itu penelitian ini bertujuan menyusun perencanaan pengelolaan sampah di jalur pendakian Taman Nasional Gunung Rinjani. Penelitian ini menggunakan beberapa metode yaitu studi literatur, wawancara dan diskusi serta survei lapangan. Berdasarkan hasil penelitian, perencanaan dalam pengelolaan sampah pada jalur pendakian Taman Nasional Gunung Rinjani dapat dirumuskan menjadi lima aspek perencanaan yaitu aspek operasional, kelembagaan, peraturan, pembiayaan, dan peran masyarakat.

Kata kunci: Sampah, perencanaan, TNGR

\section{PENDAHULUAN}

Salah satu permasalahan besar pada setiap kawasan wisata adalah sampah. Semakin hari jumlah sampah di kawasan wisata terus bertambah seiring dengan bertambahnya jumlah pengunjung, khususnya di wilayah berkumpulnya massa. 
Permasalahan sampah merupakan masalah yang selalu menjadi dilema di wilayah-wilayah pariwisata termasuk Taman Nasional Gunung Rinjani. Berdasarkan Kamalia (2016), ratarata sampah yang dihasilkan oleh seorang pendaki selama kegiatan pendakian adalah $2 \mathrm{Kg}$, apabila angka ini dikali dengan jumlah pengunjung TNGR pada tahun 2016 yang berjumlah 93.018 orang, maka perkiraan sampah yang dihasilkan dalam satu tahun adalah 186.036 $\mathrm{Kg}$. Dari data tersebut dapat dilihat bahwa permasalahan sampah patut menjadi perhatian serius, pengelola perlu melakukan upaya untuk mengurangi dampak dan kebiasaan tersebut.

Sampah adalah sisa dari bahan-bahan yang sudah mengalami perlakuan, tidak bermanfaat, dan tidak bernilai (Hadiwiyoto, 1983). Sampah memberikan banyak dampak terhadap kesehatan manusia maupun lingkungan (Suprihatin et al, 1999 dalam Utari et al, 2006). Menurut Kementerian LH (2008), pengelolaan sampah merupakan kegiatan yang sistematis dan berkesinambungan yang meliputi pengurangan dan penanganan sampah. Beberapa tahun belakangan persoalan sampah di jalur pendakian Gunung Rinjani dan sekitar Danau Segara Anak mendapat perhatian serius dari berbagai pihak. Berbagai upaya telah dilakukan oleh Balai TNGR sebagai pemangku kawasan, namun belum efektif dan belum mampu mengatasi permasalahan sampah. Program pack-in dan pack out (pemeriksaan barang bawaan berpotensi sampah) yang diterapkan kepada pengunjung belum optimal mengingat keterbatasan jumlah petugas serta rendahnya partisipasi dan kesadaran pengunjung dan penyedia jasa pemanduan wisata pendakian (guide dan porter).

Untuk mengatasi persoalan sampah yang ada, kegiatan perencanaan pengelolaan sampah khususnya di jalur pendakian Taman Nasional Gunung Rinjani menjadi penting untuk dilakukan, hal ini dibutuhkan untuk menjaring informasi dan mempersiapkan metode yang tepat dalam penanganan sampah, sehingga kedepannya rumusan strategi pemecahan masalah tersebut dapat berjalan efektif dan efisien. Tujuan dari penelitian ini adalah untuk menyusun perencanaan pengelolaan sampah berdasarkan hasil analisa permasalahan sampah pada jalur pendakian Taman Nasional Gunung Rinjani.

\section{METODE}

Penelitian ini dilaksanakan pada bulan Oktober 2017 hingga November 2018 berlokasi di Taman Nasional Gunung Rinjani. Alat yang digunakan dalam penelitian ini antaralain: GPS, alat tulis, jam tangan / stopwatch, kamera, meteran, Tally sheet. Pengambilan data dilakukan dengan metode :

\section{Studi literatur}

Studi literatur merupakan kegiatan awal berupa pengumpulan data di lapangan yang berasal dari data sekunder berupa peta, laporan kegiatan, laporan biofisik, hasil penelitian terkait khususnya mengenai sampah di jalur pendakian TNGR. Kegiatan ini bertujuan untuk memperoleh gambaran umum mengenasi kondisi lokasi penelitian.

\section{Wawancara dan diskusi}

Kegiatan wawancara dalam penelitian ini dilakukan menggunakan metode indept interview, yaitu wawancara terarah tanpa menggunakan kuisioner, wawancara bersifat mendalam, terbuka dan bersifat semi terstruktur (Sugiyono, 2010). Pemilihan responden dilakukan dengan menggunakan kaidah snowball sampling yaitu responden diperoleh melalui proses bergulir dari satu responden ke responden yang lainnya. Proses sampling ini berjalan sampai didapatkan informasi yang cukup dan tidak ada rekomendasi selanjutnya (Nurdiani, 2014). Kegiatan wawancara dipadukan pula dengan metode SWOT (Strength, weakness, opportunity, threat analisys) kepada pengelola kawasan untuk mendapatkan pemikiran dari sudut pandang pengelola. Analisis ini digunakan untuk memetakan faktor faktor yang berpengaruh dalam menyusun strategi organisasi (Rangkuti, 2009). Hasil dari analisa SWOT memetakan peluang dan ancaman serta kekuatan dan kelemahan yang dimiliki organisasi (Megaiswari, 2016). Dalam analisa SWOT terdapat pembobotan dan rating untuk setiap faktor baik kekuatan, kelemahan, peluang maupun ancaman. Bobot 
berkisar dari 1 (sangat penting) hingga 0 (tidak penting) sedangkan rating untuk kekuatan dan peluang terdiri dari 1 (sangat tidak baik), 2 (tidak baik), 3 (baik) dan 4 (sangat baik) serta kebalikaannya yaitu antara -1 hingga -4 untuk ancaman dan kelemahan. Hasil pembobotan dan rating selanjutnya digambarkan kedalam kuadran analisis.

\section{Survei lapangan}

Kegiatan survey lapangan dilakukan dalam rangka memperoleh gambaran lebih jelas mengenai kondisi lokasi penelitian khususnya mengenai sampah dan pengelolaannya. Kegiatan survey lapangan dilakukan menggunakan metode Rapid assesment. Rapid assesment merupakan metode berbasis lapangan yang fokus pada suatu lokasi dan lanskap dengan cara melakukan penilaian secara cepat dan akurat baik secara kualitatif maupun kuantitatif tentang apa yang ada dan terjadi pada suatu lokasi (IUCN, 2007).

Data hasil pengamatan disajikan secara deskriptif - kuantitatif dengan cara menyederhanakan, merata-ratakan, meringkas, dan menggolongkan data sesuai tujuan penelitian (Sugiyono, 2010)

\section{HASIL DAN PEMBAHASAN}

Berdasarkan hasil analisa SWOT yang dilakukan secara internal kepada pengelola dan berdasarkan pengamatan serta wawancara di lapangan didapat faktor internal dan juga eksternal yang mempengaruhi permasalahan sampah di Taman Nasional Gunung Rinjani. Adapun faktor internal yang menjadi kekuatan TNGR dalam pengelolaan sampah antara lain : Potensi anggaran yang cukup untuk mengelola sampah, jumlah SDM yang cukup, adanya aturan, SOP dan regulasi terkait permasalahan sampah dan penguasaan teknologi informasi yang baik. Sedangkan kelemahan yang ada antara lain : SOP yang ada belum detail mengatur kebijakan pengelolaan sampah, kurangnya sosialisasi dan pengawasan terhadap kebijakan yang ada, sanksi terhadap pelanggar belum jelas, sarana prasarana pengelolaan sampah masih kurang, sistem pengalokasian anggaran belum optimal, kapasitas dan kinerja petugas belum efektif, belum adanya instrumen monev pengelolaan sampah, database dan riset terkait sampah masih minim dan belum adanya wadah / forum untuk TNGR bersinergi mengatasi sampah.

Adapun faktor eksternal yang menjadi peluang bagi TNGR dalam mengatasi permasalahan sampah diantaranya : adanya peluang bermitra dengan masyarakat, penyelenggara wisata dan instansi terkait dalam pengelolaan sampah, adanya dukungan kebijakan secara vertikal (pemerintah) melalui aturan dan kebijakan yang sudah dikeluarkan dan adanya potensi pemanfaatan / pengeloahan sampah bersama para mitra. Sedangkan faktor yang menjadi ancaman yaitu : tren kenaikan angka kunjungan wisatawan (potensi sampah yang dibawa pengunjung), adanya potensi penolakan bagi kebijakan yang merugikan pelaku wisata dan rendahnya pemahaman pelaku wisata

Berdasarkan hasil analisa, keempat faktor berdasarkan SWOT diatas apabila dikelompokkan lebih lanjut terdiri dari lima hal yaitu:

1. Aspek operasional, aspek ini berkaitan dengan bagaimana pengelolaan sistem atau model pengelolaan sampah, sarana dan prasarana pengelolaan, teknis dan teknologi yang digunakan, serta instrumen evaluasi yang digunakan.

2. Aspek kelembagaan, aspek ini berkaitan dengan bagaimana pengelolaan lembaga dan sumberdayanya dalam menggerakkan sistem operasional, meliputi pembagian tugas dan tanggung jawab selain itu juga berkaitan dengan pembangunan kerjasama dengan instansi terkait.

3. Aspek peraturan, aspek ini berkaitan dengan bagaimana pengelolaan aturan dan pembuatan regulasi yang jelas sehingga mampu mengurangi dan mencegah timbulnya permasalahan sampah

4. Aspek pembiayaan, aspek ini berkaitan dengan bagaimana pengelolaan keuangan meliputi mekanisme pembiayaan, sumber, alokasi anggaran, dan penggunaan anggaran untuk mengelola sampah 
5. Aspek peran masyarakat, merupakan aspek yang mendukung berjalannya sistem pengelolaan sampah, meliputi upaya - upaya sosialisasi, edukasi dan pendampingan kepada masyarakat.

\section{Perencanaan Pengelolaan Sampah}

Sistem pengelolaan sampah Taman Nasional Gunung Rinjani dirumuskan kedalam 5 (lima) aspek atau komponen strategi yang diperolah dari hasil analisa situasi (SWOT) yaitu :

\section{A. Aspek operasional}

Berdasarkan Undang-Undang Nomor 18 Tahun 2008 Tentang Pengelolaan Sampah, strategi penanggulangan sampah dapat dilakukan dengan konsep 3R, yaitu Reduce (mengurangi), Reuse (menggunakan kembali) dan Recycle (mendaur ulang). Dalam konsep 3R sampah harus dikurangi dari awal ketika pengunjung masuk ke kawasan Taman Nasional. Pada tingkat operasional sistem ini dapat juga dipadukan dengan kegiatan pemilahan. Sampah yang dapat didaur ulang umumnya berupa plastik, kertas, botol dan besi harus dipilah diawal, karena barang-barang tersebut dapat didaur ulang dan umumnya mempunyai nilai ekonomi. Dalam pemilahan sampah, tidak hanya diperlukan keterampilan petugas saja, tapi juga diperlukan sistem pengelolaan sampah yang sudah memadai, baik berupa sarana-sarana fisik maupun peralatan. seperti misalnya tempat sampah terpilah, gerobak terpilah, jadwal pengangkutan dengan konsistensi atau sistem yang berkesinambungan. Sampah B3 yang tidak bisa di daur ulang seperti batrei ditempatkan pada tempat sampah dengan warna dan lambang tertentu dan dipindahkan (angkut) ke lokasi yang aman, dapat juga bekerja sama dengan pemerintah daerah untuk pengolahan selanjutnya. Adapun lingkup penanganan sampah dengan sistem 3R secara terperinci adalah sebagai berikut:

1. Pembatasan sampah

Beberapa barang yang berpotensi menyebabkan sampah dan menimbulkan dampak terhadap lingkungan perlu dibatasi untuk dibawa masuk ke dalam kawasan. Adapun barang berupa sampah dan dilarang masuk ke dalam kawasan Taman Nasional Gunung Rinjani khususnya pada kegiatan pendakian adalah sebagai berikut:

a. Sampah plastik seperti air minum dan makanan dalam kemasan plastik serta kantong plastik. Membawa air minum dan makanan diharuskan menggunakan wadah isi ulang (kontainer plastik atau dirigen).

b. Sampah kaleng seperti air minum dan makanan kaleng. Air minum dan makanan kaleng dicatat atau difoto untuk diregestrasi sebagai barang bawaan yang akan di cek ulang pada saat turun dari gunung.

c. Sampah kaca seperti air minum dan makanan dalam kemasan kaca. Air minum dan makanan dalam kemasan kaca dicatat atau difoto untuk diregestrasi sebagai barang bawaan yang akan di cek ulang pada saat turun dari gunung.

d. Tisu basah, bungkus permen, stereofoam merupakan jenis sampah yang sulit terurai sehingga dilarang dibawa oleh pendaki.

e. Sabun, shampoo, dan deterjen berbahan kimia merupakan jenis zat pencemar lingkungan sehingga dilarang dibawa oleh pendaki.

\section{Pewadahan sampah}

Kegiatan pewadahan sampah adalah upaya yang dilakukan dengan tujuan untuk memisahkan atau mengelompokkan sampah berdasarkan karakteristik dan jenisnya. Berdasarkan SNI 19-2454-2002 Tentang Tata Cara Teknik Operasional Pengelolaan Sampah, pewadahan sampah harus dilakukan mulai dari sumbernya secara terpadu. Pewadahan sampah akan mempermudah pengelola dalam menindaklanjuti atau memproses sampah yang sudah terkumpul. Dalam kegiatan pewadahan, sampah dibedakan menjadi sampah basah atau organik, kering atau anorganik, dan sampah B3 atau bahan beracun dan berbahaya. Kegiatan pewadahan sampah sebaiknya menggunakan perbedaan kode warna seperti hijau untuk sampah organik, kuning untuk anorganik dan merah untuk sampah B3. 


\section{Sarana dan Prasarana}

Sarana dan prasarana pada aspek operasional merujuk pada alat pengumpul atau armada sampah serta papan informasi. Alat pengumpul dapat berupa gerobak, motor atau becak, mobil bak maupun kuda. Berdasarkan pengamatan dilapangan, penggunaan kuda sebagai armada pengangkut sampah adalah memungkinkan khususnya di jalur Sembalun, karena kuda mampu melewati medan berat yang tidak dapat dilalui oleh kendaraan biasa. Perhitungan kebutuhan jumlah armada sampah harus didasarkan pada perbandingan daya tampung armada perunit dan total volume sampah yang dihasilkan. Pada lokasi terkonsentrasinya pengunjung hendaknya terdapat papan informasi seperti papan himbauan, petunjuk arah dan papan larangan untuk mempermudah dan mengatur pengunjung.

\section{B. Aspek kelembagaan}

Dalam struktur organisasi Taman Nasional secara umum tidak terdapat unit atau divisi khusus yang melakukan kegiatan pengelolaan sampah, oleh karena itu dibutuhkan suatu lembaga yang nantinya dapat menjalankan kegiatan pengelolaan sampah secara mandiri. Berdasarkan hasil analisa, dalam rangka penanganan sampah, maka bentuk kelembagaan yang sesuai untuk penanganan sampah di Taman Nasional Gunung Rinjani diantaranya adalah :

a. Kelompok masyarakat peduli sampah. Kelompok ini harus memiliki badan hukum, sehingga kelompok kelompok ini menjadi mitra dalam penanganan sampah.

b. Relawan sampah, kelompok ini berupa individu atau kelompok yang dapat di organisir menjadi relawan dalam menangani sampah di kawasan TNGR.

c. Skema ijin usaha penyedia jasa wisata alam bagi pihak ketiga (kelompok masyarakat atau badan usaha)

\section{Aspek peraturan}

Peraturan dibutuhkan untuk mengawal kebijakan yang sudah dirancang oleh pengelola khususnya mengenai kebijakan pegelolaan sampah. Adanya peraturan dimaksudkan untuk memberikan batasan dan ketetapan yang standar kepada pengunjung sehingga pengunjung dapat tertib selama berwisata dan terwujud suatu sistem penanganan sampah yang baik, adapun kebutuhan perangkat peraturan meliputi :

a. Persyaratan pendakian di Taman Nasional Gunung Rinjani.

b. Kewajiban, larangan, dan sanksi pendakian di Taman Nasional Gunung Rinjani.

c. Alur pengunjung dan prosedur pembelian tiket di Taman Nasional Gunung Rinjani.

d. Prosedur pemeriksaan barang bawaan pendakian di Taman Nasional Gunung Rinjani.

e. Jadwal pendakian, batas pengunjung, dan penutupan pendakian di Taman Nasional Gunung Rinjani.

\section{Aspek pembiayaan}

Pembiayaan merupakan salah satu faktor penggerak kebijakan dalam pengelolaan sampah. Pembiayaan pengelolaan sampah merupakan dana atau biaya yang dikeluarkan secara rutin untuk melakukan penanganan sampah. Biaya yang dibutuhkan dalam pengeolaan sampah utamanya meliputi biaya operasional, pengadaaan sarana prasarana dan pemeliharaan sarana prasarana (SNI-T-12-1991-03 tentang Operasional Pengelolaan Sampah Perkotaan) sedangkan pembiayaan dalam pengelolaan sampah pendakian Gunung Rinjani berdasarkan hasil diskusi dan analisa adalah sebagai berikut :

a. Biaya pengadaan sarana dan prasarana

b. Biaya pengumpulan dan pemilahan

c. Biaya pengolahan sampah

d. Biaya edukasi

e. Biaya pengawasan dan pemeliharaan

Sumber pembiayaan pengelolaan sampah pendakian Taman Nasional Gunung Rinjani berasal dari : 

a. DIPA Balai Taman Nasional Gunung Rinjani
b. APBD Provinsi NTB
c. APBD Kabupaten Lombok Utara, Lombok Timur, Lombok Tengah
d. APBN melalui Kementerian terkait
e. Dana CSR perusahaan
f. Swadaya masyarakat

\section{E. Aspek peran masyarakat dan stakeholder}

Peran serta masyarakat setempat termasuk masyarakat yang terlibat dalam penyediaan jasa wisata khususnya pendakian sangat dibutuhkan dalam program pengelolaan sampah Taman Nasional Gunung Rinjani. Peran serta masyarakat berkaitan dengan pengelolaan persampahan dapat ditingkatkan dengan kegiatan seperti :

a. Sosialisasi, sosialisasi dapat dilakukan secara reguler. Dilakukan oleh staf TNGR di tingkat Resort. Setiap staff resort harus memiliki sertifikat ketrampilan penyuluh sampah.

b. Edukasi, dilakukan kegiatan penyadartahuan berkaitan dengan sampah, dapat dilakukan kepada masyarakat, generasi muda, maupun di sekolah dasar di lingkungan sekitar TNGR. Tujuan edukasi adalah dalam jangka panjang terjadi perubahan perilaku dan mindset mengenai sampah dan permasalahannya.

c. Pelatihan dan capacity building bagi penyelenggara wisata terkait pengelolaan sampah. Pelatihan diberikan kepada masyarakat secara reguler. Untuk mengefisienkan anggaran dilakukan TOT (training of trainer)kepada staf TNGR yang bertugas di setiap resort.

d. Sertifikasi bagi penyelenggara wisata terkait pemahaman mengenai pengelolaan sampah. Dengan tersertifikasi, pemandu gunung dan porter diharapkan memiliki kualitas dan pengetahuan yang baik. Tidak hanya soal mendaki gunung, melainkan juga dalam hal menjaga kelestarian alam. Pelatihan pada pemandu gunung dan porter Gunung Rinjani meliputi masalah safety procedure pendakian, kebersihan, dan juga pelayanan.

e. Pembuatan aturan lokal (awik-awik) ditingkat penyelenggara wisata berisi reward and punisment baik kepada anggota maupun wisatawan mengenai kepedulian terhadap sampah

\section{KESIMPULAN}

Berdasarkan hasil penelitian, perencanaan dalam pengelolaan sampah pada jalur pendakian Taman Nasional Gunung Rinjani dapat dirumuskan menjadi lima aspek pengelolaan yaitu aspek a). Operasional meliputi pembatasan sampah, pewadahan sampah dan pemenuhan sarpras, b). kelembagaan meliputi pembentukan kelompok dan ijin usaha, c). Penyusunan perangkat peraturan, d). Identifikasi pembiayaan dan e). Penguatan peran serta masyarakat.

\section{DAFTAR PUSTAKA}

[BSN] Badan Standarisasi Nasional. 1991. Operasional Pengelolaan Sampah Perkotaan SNI-T-12-1991-03. Jakarta. BSN.

[BSN] Badan Standarisasi Nasional. 2002. Tata cara teknik operasional pengeloaan sampah perkotaan SNI 19-2454-2002. Jakarta. BSN.

Hadiwiyoto, S. 1983. Penanganan dan Pemanfaatan Sampah. Jakarta. Yayasan Idayu.

IUCN. 2007. Common Guidelines and Methodology for Rapid Field Assessment - Tsunami Damage to Terrestrial Coastal Ecosystems. United Kingdom. IUCN Publications Services Unit.

Kamalia, A.A.A. 2016. Peran Nilai Personal terhadap Perilaku Pro-lingkungan pada Pendaki Gunung. [Skripsi] Fakultas Psikologi Universitas Indonesia

Kementerian Negara Lingkungan Hidup. 2008. Undang Undang Republik Indonesia No.18 Tahun 2008 tentang Pengelolan Sampah. Jakarta. 
Megaiswari, N. 2016. Manfaat ekonomi dan strategi pengelolaan sampah perkotaan. [Skripsi] Fakultas ekonomi manajemen Institut Pertanian Bogor.

Nurdiani N. 2014. Teknik Sampling Snowball Dalam Penelitian Lapangan. Comtech. 5 (2): $1110-1118$.

Rangkuti, F. 2009. Analisis SWOT Teknik Membedah kasus Bisnis. Jakarta. Gramedia pustaka Utama.

Sugiyono. 2010. Metode Penelitian Kuantitatif Kualitatif dan R\&D. Bandung. Alfabeta.

Utari, R. K., Pearce, D. \& Batemen, I. 2006. Environmental Economics: An Elementary Introduction. Hertfords. Harvester Wheatsheaf. 